\title{
Percent Predicted Slow Vital Capacity
}

National Cancer Institute

\section{Source}

National Cancer Institute. Percent Predicted Slow Vital Capacity. NCI Thesaurus. Code C112386.

The maximum volume of air that can be exhaled after slow maximum inhalation as a proportion of the predicted normal value. (CDISC) 